\title{
Investigation of Telomerase Activity in Inflammatory and Non Inflammatory Breast Cancer
}

\author{
Ayman Maher Ibrahim ${ }^{1 *}$, Salwa Farouk Sabet ${ }^{1}$ and Mohamed El-Shinawi ${ }^{2}$ \\ ${ }^{1}$ Faculty of Science, Cairo University, Egypt \\ ${ }^{2}$ Associate Professor of General Surgery, Ain Shams University, Cairo, Egypt
}

\begin{abstract}
Background: Inflammatory breast cancer (IBC) is an aggressive type of breast cancer disease that has a high incidence in Egypt than western countries. It is characterized by rapid progression, involvement of dermal lymphatic emboli and extensive lymph node involvement. Basic and translational studies are needed to define IBC disease biology and identify specific biomarkers have been limited by the paucity of patient samples. Hence, the current study aimed to introduce the telomerase activity level as a novel diagnostic marker for breast cancer and specifically for IBC to be differentiated from non-IBC.

Methods: Breast cancer patients were enrolled from Ain Shams University hospitals in Cairo, divided into two groups: IBC $(n=26)$ and non-IBC $(n=27)$. Tissue samples were collected during modified radical mastectomy. TRAP (Telomerase repeat amplification protocol) assay was used to assess the telomerase activity in inflammatory and non inflammatory breast cancer tissue samples. Immunohistochemistry was used to investigate the expression of hTERT subunit of telomerase in paraffin embedded
\end{abstract} tissue samples of both types of patients.

Results: IBC showed Telomerase activity ranged from 12.2 to 367.1 units with a mean value of 78 and a median value of 43 while telomerase activity in non-IBC ranged from 6.1 to 109.34 units with a mean value of 41.1 and a median value of 24 . On the other hand, normal tissues showed telomerase activity below $5(\mathrm{P}<0.001)$. Using immunohistochemistry, the hTERT expression was higher in IBC than non-IBC and no expression at all in normal tissues. Moreover, a positive mild correlation was found between the telomerase activity and the number of metastatic lymph nodes in both IBC $(r=0.53)$ and non-IBC $(r=0.54)$.

Conclusions: Telomerase could be a promising marker at the diagnostic and therapeutic levels in breast cancer and specifically in IBC.

Keywords: Breast cancer; Cancer death; Erythema; Telomerase

\section{Introduction}

Breast cancer is the most frequently diagnosed cancer and the leading cause of cancer death among females, accounting for $23 \%$ of the total cancer cases and $14 \%$ of the cancer deaths. Recent statistics revealed that approximately 207,090 new cases of invasive breast cancer and 40,230 deaths from disease were diagnosed in USA in 2010 [1].

In Egypt, breast cancer is number one among women constituting about $38.6 \%$ of female cancer cases (National cancer registry program of Egypt, 2010) and it was found that it is more prominent among young premenopausal Egyptian women characterized by poor prognosis and low survival rate [2].

Most of Egyptian patients are diagnosed at advanced stage (II and III) (Gharbiah population-based cancer registry, 2007 and National cancer registry program of Egypt, 2010) and most cases possess positive axillary lymph node metastasis about $70.6 \%$ at the time of diagnosis while only $29.4 \%$ are free of metastasis [3]. Besides, IBC occurs in approximately $1-6 \%$ of all breast cancers in the U.S [4,5], in Egypt it occurs in approximately $10 \%$ of all breast cancers [6], which reflects the invasive properties of breast cancer in Egyptian patients.

As a subtype, inflammatory breast cancer (IBC) is the most aggressive apparition of primary epithelial breast cancer and it belongs to the group of locally advanced breast cancer (LABC) characterized by a variety of clinical presentations including large tumors, extensive nodal involvement and direct involvement of the skin or chest wall. IBC is a clinicopathological entity characterized by the rapid onset of swelling and often enlargement of the breast. Although the overlying skin remains intact, it displays erythema often combined with 'peau d'orange', local tenderness, induration and warmth. All these changes can occur to a variable degree. Critical in this definition is the rapidity with which these occur [7-10]. According to the population-based cancer registry in Egypt, IBC cases represent around 11.1\% of breast cancer cases between Egyptian patients and this percentage is on the rise [11].

The aggressive nature of IBC, in addition to the unique molecular and epidemiological characteristics supports the hypothesis that IBC has its own characters rather than being a subtype of locally advanced breast cancer $[8,12,13]$. For instance IBC can be distinguished from the LABC by the presence of numerous dermal tumor emboli in the papillary and reticular dermis of the skin overlying the breast $[8,14-16]$.

The rapid onset, the misdiagnosis and lack of enough biological markers of IBC make it very critical to introduce new molecular and biological markers to accurately and early diagnose the disease.

Human telomerase is a ribonucleoprotein enzyme composed of catalytic component, telomerase reverse-transcriptase (TERT) $[17,18]$ and RNA template TERC (or hTR), telomerase RNA component (or human telomerase RNA) [19]. Telomerase can elongate the G-rich 3' telomere overhang by adding (TTAGGG) repeats using its RNA as a template [20].

*Corresponding author: Ayman Maher Abdel Moneem Ibrahim, Assistant Lecturer Faculty of Science, Cairo University, Egypt, E-mail: sci_ayman@yahoo.com

Received September 06, 2012; Accepted October 02, 2012; Published October 04, 2012

Citation: Ibrahim AM, Sabet SF, El-Shinawi M (2012) Investigation of Telomerase Activity in Inflammatory and Non Inflammatory Breast Cancer. J Cancer Sci Ther 4 360-367. doi:10.4172/1948-5956.1000168

Copyright: (c) 2012 Ibrahim AM, et al. This is an open-access article distributed under the terms of the Creative Commons Attribution License, which permits unrestricted use, distribution, and reproduction in any medium, provided the original author and source are credited. 
In most human normal somatic cells, telomerase activity is undetectable [21]. Every type of human malignancy examined to the present time has evidence that $>80 \%$ of overall malignancies have telomerase activation with different levels [22].

At carcinogenesis early stages, cancer cells do not require telomerase activity unless their telomere lengths become critically shortened, since carcinogenesis and cellular immortalization are independent processes. However, in advanced stages, most cancer cells have experienced several clonal selections, especially those in metastatic lesions since metastasis itself adds at least one clonal selection, and subsequently many cell divisions. At such stages, most cancer cells depend on telomerase to proceed in the proliferation rounds. Hence, activation of telomerase itself likely provides more malignant potential like what occurs in metastasis [22-24].

In a study conducted by Koskimaa et al. [25] they showed an up-regulation for telomerase activity in Cervical cancer. Similarly, telomerase activity was detected in bladder cancer as a diagnostic target [26]. Telomerase activity was investigated in bronchial epithelium for lung cancer detection and diagnostic purposes as well [27,28], and in colorectal cancer for prognostic significance value [29] and many other cancers either involved in telomerase studies or still under investigation.

Moreover, Shay and Bacchetti [22] reviewed that telomerase activity was $75 \%$ of breast carcinoma in situ lesions, $88 \%$ of ductal and lobular carcinomas, $5 \%$ of adjacent tissues and other more studies confirmed these results and did more investigation on different types and stages [30-32].

Besides, Telomerase inhibition should be effective and specific, while normal cells lacking telomerase should not be significantly affected by anti-telomerase therapy. Since telomerase expression in cancer cells can be used as a novel marker for screening, early detection, and prognosis, clinical trials are already in progress to assess this potential $[33,34]$.

Thus, telomerase components and its associated proteins are becoming not only a diagnostic marker of cancer but also a promising molecular target of anticancer strategies and some of them are under clinical trials.

The purpose of this study was to investigate telomerase activity in inflammatory and non-inflammatory breast cancer and its correlation with the type and stage of cancer.

\section{Materials and Methods}

\section{Study patients}

The study was approved by the Institutional Review Board of Ain Shams University Ethic committee (IRB \#.00006379). 26 IBC and 27 non IBC patients were enrolled in the study, and the clinical and pathological information of these patients was collected from the hospital records and pathology reports (Table 1).

Inclusion criteria of breast cancer patients were dependent upon a combination of clinical, mammographic, ultrasound, and pathological diagnoses.

Clinical diagnosis of IBC is applied, according to the American Joint Committee on Cancer (AJCC) T4 d designation for IBC [8], when a patient presented with a diffuse erythema, peau d'orange and edema of the breast. For IBC patients, pathological confirmation of the clinical diagnosis was dependent upon examination of both skin and core biopsies (M.A.N.). In the absence of breast masses, diagnosis was depended upon pathological examination of skin biopsies that showed permeation of dermal lymphatics by carcinoma cells and the presence of dermal tumor emboli (M.A.N.) (Figure 1). Non-IBC patients of stage II-III were also included in our study as a comparison group.

Patients subjected to neo-adjuvant chemotherapy or those with viral hepatitis or autoimmune disease were excluded from our study. Tissue specimens were obtained from modified radical mastectomy (MRM) specimens. All tumor tissues preserved in 10\% neutral formalin buffer for histopathological diagnosis and immunohistochemistry. Fresh tissues were available for all patients (26 IBC and 27 non-IBC) and 5 normal tissues obtained from healthy volunteers underwent mammoplastic (Breast reduction) surgery (Mean age $27.8 \pm 5.9$ ). Tissues were preserved in freezing media (70\% RPMI 1640, 20\% Fetal Bovine Serum (FBS) and 10\% dimethyl sulfoxide (DMSO) and stored at $-80^{\circ} \mathrm{C}$ until used.

Pathological diagnosis was examined for each patient, including tumor size, tumor grade, disease stage, lymph node status and presence or absence of lymphovascular invasion and dermal lymphatic emboli. According to the modified Bloom Richardson- Elston histological system, tumors divided into I, II and III grades as well as breast cancer is staged into four main stages from I to IV based on TNM classification [35].

\section{TRAP (Telomerase Repeat Amplification Protocol) Assay}

TRAP assay is a sensitive PCR-based telomerase activity detection method that could detect telomerase activity in human tissue and cells. The assay, which was originally described by Kim et al. [36], is a one buffer with two enzymes system utilizing the polymerase chain

\begin{tabular}{|c|c|c|c|}
\hline Characteristic & IBC $n=26(\%)$ & $\begin{array}{c}\text { Non-IBC } n=27 \\
(\%)\end{array}$ & $P$-value \\
\hline $\begin{array}{l}\text { Age } \\
\begin{array}{c}\text { Range } \\
\text { mean }\end{array}\end{array}$ & $\begin{array}{c}29-72 \\
51 \pm 12.3\end{array}$ & $\begin{array}{c}37-78 \\
55 \pm 10.5\end{array}$ & $>0.05$ \\
\hline $\begin{array}{r}\text { Tumor size } \\
\leq 2 \\
>2 \\
\text { NA }\end{array}$ & $\begin{array}{c}2(8 \%) \\
23(92 \%) \\
1\end{array}$ & $\begin{array}{c}2(10 \%) \\
20(90 \%) \\
5\end{array}$ & $>0.05$ \\
\hline $\begin{array}{l}\text { Number of Positive } \\
\text { Lymph nodes } \\
\qquad 4 \\
\geq 4 \\
\text { NA }\end{array}$ & $\begin{array}{c}6(24 \%) \\
19(76 \%) \\
1\end{array}$ & $\begin{array}{c}16(61 \%) \\
6(39 \%) \\
5\end{array}$ & $<0.001^{* *}$ \\
\hline $\begin{array}{c}\text { Tumor grade } \\
\text { Grade I-II } \\
\text { Grade III } \\
\text { NA }\end{array}$ & $\begin{array}{c}18(81 \%) \\
4(19 \%) \\
4\end{array}$ & $\begin{array}{c}18(86 \%) \\
3(14 \%) \\
6\end{array}$ & $>0.05$ \\
\hline $\begin{array}{l}\text { Negative } \\
\text { Positive } \\
\text { NA }\end{array}$ & $\begin{array}{c}11(55 \%) \\
9(45 \%) \\
6\end{array}$ & $\begin{array}{c}12(63 \%) \\
7(37 \%) \\
8\end{array}$ & $>0.05$ \\
\hline $\begin{array}{l}\text { Negative } \\
\text { Positive } \\
\text { NA }\end{array}$ & $\begin{array}{c}9(45 \%) \\
11(55 \%) \\
6\end{array}$ & $\begin{array}{c}12(63 \%) \\
7(37 \%) \\
8\end{array}$ & $>0.05$ \\
\hline $\begin{array}{l}\text { HER-2 } \\
\text { Negative } \\
\text { Positive } \\
\text { NA }\end{array}$ & $\begin{array}{c}14(82 \%) \\
3(18 \%) \\
1\end{array}$ & $\begin{array}{c}15(79 \%) \\
4(21 \%) \\
8\end{array}$ & $>0.05$ \\
\hline
\end{tabular}

$\mathrm{NA}=$ is the number of patients had no available data; $\mathrm{n}=$ number of patients; $\mathrm{P}<0.001=$ Extremely significant difference; $\mathrm{P}>0.05=$ non-significant difference

Table 1: Clinical and pathological characteristics of IBC and non-IBC patients. 


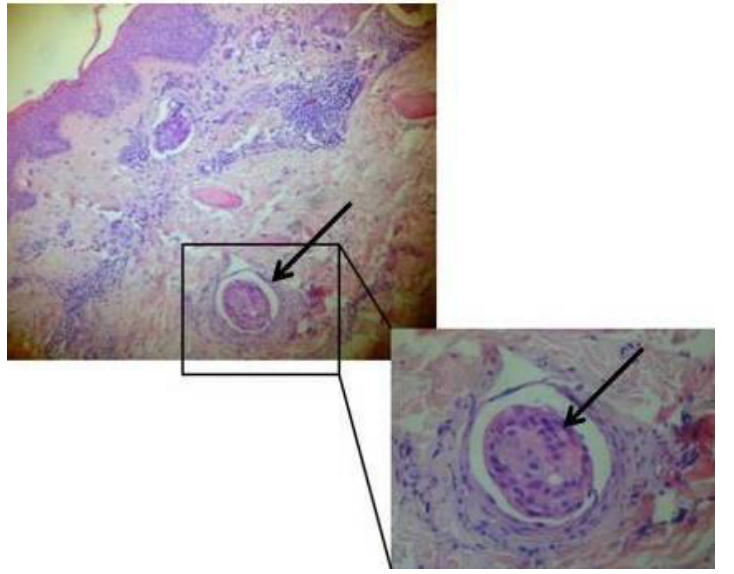

Figure 1: Tissue section of inflammatory breast cancer case enrolled in our study demonstrates the lymphovascular tumor emboli and on the right a magnified embolus. Original magnifications, X100 (left image) and X400 (right magnified image)

reaction (PCR). In the first step of the reaction, telomerase adds a number of telomeric repeats (GGTTAG) onto the 3' end of a substrate oligonucleotide (TS). In the second step, the extended products are amplified by PCR using the TS and RP (reverse) primers, generating a ladder of products with 6 base increments starting at 50 nucleotides: 50 , $56,62,68$, etc. Hence, if there is telomerase activity, a ladder of bands will be detected starting from $50 \mathrm{bp}$ and if not, only the $36 \mathrm{bp}$ band will be detected.

TRAPeze Telomerase Detection kit (catalog number \#S7700) was purchased from Chemicon International, Inc (Millipore, USA). Bradford reagent (catalog number R1271), Ribolock RNAase inhibitor (catalog number Eo0381), Dream taq DNA polymerase (catalog number Ep0702) and Maxima Hot start taq DNA polymerase (catalog number Ep0601) were purchased from Fermentas (R 1271, Fermentas, Burlington, ON, Canada). SYBR green I (catalog number S9430) was purchased from SIGMA (St. Louis, MO).

Tissue extract was prepared using 1X CHAPS lysis buffer $(10 \mathrm{mM}$ Tris-HCl, pH 7.5, 1 mM MgCl2, 1 mM EGTA, 0.1 mM Benzamidine, $5 \mathrm{mM} \beta$-mercaptoethanol, 0.5\% CHAPS, 10\% Glycerol) supplied with the TRAPeze telomerase detection kit. RNase inhibitor was added to the CHAPS Lysis Buffer prior to the extraction for a final concentration of $100-200$ units/mL.

Extracts containing $5 \mu$ g protein were added to the TRAP reaction mixture containing $2.5 \mu \mathrm{l}$ of 10X TRAP reaction buffer (200 mM Tris$\mathrm{HCl}, \mathrm{pH} 8.3,15 \mathrm{mM} \mathrm{MgCl}_{2}, 630 \mathrm{mM} \mathrm{KCl}, 0.5 \%$ Tween 20, $10 \mathrm{mM}$ EGTA), $0.5 \mu \mathrm{l}$ of $50 \mathrm{X}$ dNTP mix (2.5 mM each dATP, dTTP, dGTP, dCTP), $0.5 \mu \mathrm{l}$ TS primer, $0.5 \mu \mathrm{l}$ TRAP primer mix (RP primer, K1 primer, TSK1 template), $0.3 \mu$ l of Hot start Taq polymerase (5 units/ $\mu \mathrm{l})$, and $\pm 18.8 \mu \mathrm{l}$ of PCR grade water.

Reaction tubes were incubated in thermocycler at $30^{\circ} \mathrm{C}$ for $30 \mathrm{~min}$. This step of the TRAP assay allows telomerase of cell lysates to add hexamer repeats of telomeric sequence (TTAGGG) onto the 3 '-end of the included primer. The reaction mixtures were then subjected to conventional polymerase chain reaction consisted of 34 PCR cycles of $94^{\circ} \mathrm{C}$ for $30 \mathrm{sec}, 59^{\circ} \mathrm{C}$ for $30 \mathrm{sec}$ and $72^{\circ} \mathrm{C}$ for $1 \mathrm{~min}$ followed by a final extension step for at $72^{\circ} \mathrm{C}$ for $5 \mathrm{~min}$.

To re-amplify the PCR product for better visualization, a second
PCR run took place by adding $5 \mu$ of the $1^{\text {st }}$ PCR product to $20 \mu \mathrm{l}$ of the master mix.

The PCR products were analyzed by electrophoresis at $100 \mathrm{~V}$ for about $1.5 \mathrm{~h}$ on a $15 \%$ polyacrylamide gel and the gel was stained with SYBR Green I nucleic acid gel stain.

Telomerase activity was assessed by measuring the intensity of bands in the whole lane of each sample compared to the TSR8 quantitation control (Q) using ImageJ software according to the following formula as described by Gümüş-Akay et al. [37].

Telomerase activity $(\mathrm{TA})=([\mathrm{X} / \mathrm{C}] /[\mathrm{r} / \mathrm{Cr}]) \times 50$

Where $\mathrm{X}$ is the intensity of the telomerase ladder of the test sample, $\mathrm{C}$ is the intensity of the internal standard (two primers in each reaction mixture for amplification of a $36 \mathrm{bp}$ standard) in the test sample, $r$ is the intensity of the TSR8 quantitation control (a telomerase product-like ladder for comparison with the test sample), and $\mathrm{Cr}$ is the intensity of the internal standard in TSR8 quantitation control.

TSR8 quantitation control (Q) is an oligonucleotide, provided with the kit, with a sequence identical to the TS primer extended with 8 telomeric repeats AG(GGTTAG). This control serves as a standard for estimating the amount of TS primers with telomeric repeats extended by telomerase in a given extract.

\section{Immunohistochemistry (IHC) for telomerase enzyme in tissue blocks}

Super Sensitive ${ }^{\mathrm{TM}}$ Polymer-HRP IHC Detection System/DAB (catalog number QD420-YIKE*) and universal blocking reagent (10X) (catalog number HK085-5K) were purchased from Biogenex (Fremont CA U.S.A.). Rabbit monoclonal antibody anti human telomerase (catalog number EST21-A) was purchased from Alpha Diagnostic Int. Co., (San Antonio, TX, USA). Unless otherwise stated all other reagents were from Sigma (St. Louis, MO).

Tissue sections were prepared from paraffin blocks and stained with hematoxylin and eosin to select tissue sections for immunostaining and scoring. IHC staining was performed on $5 \mu \mathrm{m}$ thick tissue sections. Tissue sections were first deparaffinized and rehydrated followed by antigen retrieval by heating with pressure cooker for 5-7 mins. Blocking was performed using peroxidase blocking reagent then serum blocking.

Tissue sections were incubated overnight with the primary antibody prepared in Dako Antibody diluent with reduced background components at $5 \mu \mathrm{g}$ concentration polyclonal anti hTERT.

Detection was then completed by incubating tissue sections with $50 \mu \mathrm{l}$ of super inhancer for 20 mins and $50 \mu \mathrm{l}$ of polymer - HRP for 30 mins. Then staining was performed by adding $50 \mu \mathrm{l}$ of DAB for 5 mins. Nuclei were counterstained with hematoxylin and specimens were rinsed in alkaline water and mounted using Permount ${ }^{\circledR}$ for microscopic examination.

\section{Statistical analysis}

Results analysis was performed using statistical package for the social sciences software (SPSS, Chicago, IL), version 16.0. Qualitative data were expressed as frequencies and percentages while quantitative data were expressed as mean \pm SE.

The analysis of telomerase activity between populations was tested using Kruskal-Wallis one-way analysis of variance (Chi-square) [38] for testing equality of population medians among groups. 
Citation: Ibrahim AM, Sabet SF, El-Shinawi M (2012) Investigation of Telomerase Activity in Inflammatory and Non Inflammatory Breast Cancer. J Cancer Sci Ther 4: 360-367. doi:10.4172/1948-5956.1000168

The correlation between telomerase activity and number of metastatic lymph nodes was assessed using Pearson product-moment correlation coefficient (PPMCC) to measure of the strength of linear dependence between the two variables.

\section{Results}

\section{Clinical and pathological characterization of IBC versus non- IBC patients}

Clinical and pathological characterization of the IBC $(n=26)$ and non-IBC patients $(n=7)$ used in this study is indicated in table 1 . Age of IBC patients ranged from 29-72 years (mean age of $51 \pm 12.3$ ), whereas the age of non-IBC patients ranged from 37-78 years (median age of $55 \pm 10.5)$

For IBC patients, $8 \%$ of them exhibited tumor masses less than 2 $\mathrm{cm}$ and $92 \%$ had a tumor mass more than $2 \mathrm{~cm}$. Non-IBC patients had tumor with $10 \%$ having tumor sizes less than $2 \mathrm{~cm}$ and $90 \%$ having tumor sizes greater than or equal to $2 \mathrm{~cm}$. Tumor grading revealed that $81 \%$ of IBC patients were tumor grade I or II and $19 \%$ were tumor grade III. In non-IBC patients $86 \%$ were diagnosed as tumor grade I or II, and $14 \%$ were diagnosed as tumor grade III.

We assessed the number of axillary lymph nodes that were positive for metastases in IBC versus non-IBC patients. All IBC patients who underwent surgery had positive metastatic lymph nodes: $24 \%$ had less than 4 positive metastatic lymph nodes, $76 \%$ had more than or equal 4 positive metastatic lymph nodes. Among non-IBC patients, $61 \%$ had less than 4 metastatic lymph nodes ( 2 patients in this category had no metastatic lymph nodes) and $39 \%$ had more than or equal 4 metastatic lymph nodes. In addition, the difference between the number of positive metastatic lymph nodes in IBC versus non-IBC patients was determined to be statistically significant $(\mathrm{P}<0.001)$.

Positive staining for ER, PR and HER-2 was detected in 45\%, 55\% and $18 \%$ of the IBC patients, respectively. In non-IBC patients, positive staining for ER, PR and HER- 2 was $37 \%, 37 \%$ and $21 \%$, respectively.

\section{Telomerase activity in IBC, non IBC and normal tissues}

To compare relative amounts of telomerase activity between samples, the TRAP assay signals of the telomerase ladder (50 bp+6 bp increment-ladders according to the activity) were normalized to that of the internal standard (36 bp) (Figure 2).

In our study, telomerase activity was detected in all the breast cancer tissues either inflammatory or non inflammatory but the level of activity was variable.

In IBC tissue samples, telomerase activity ranged from 12.2 to 367.1 and the mean value were 78 with a standard deviation of 87.4.In NIBC tissue samples, telomerase activity ranged from 6.1 to 109.34 and the mean value was 41.1 with a standard deviation of 30.7. In normal tissues, all the values were equal or below 5 (Figure 3).

These values represent the relative telomerase activity with a constant protein concentration for all the samples.

We compared telomerase activity between IBC, non-IBC and normal samples using Kruskal-Wallis one-way analysis of variance (Chi-square) test and the result showed statistical significance $(\mathrm{P}<0.001)$.

Moreover, post Hoc tests by multiple comparisons were made comparing groups in pairs as follows; the difference in telomerase

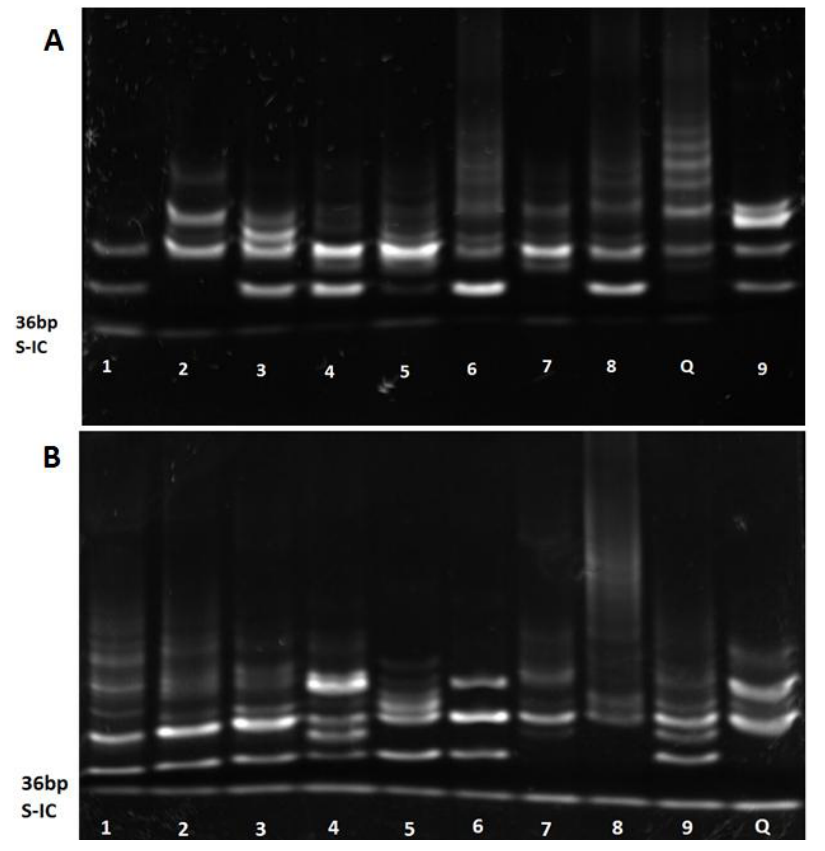

Figure 2: Detection of Telomerase activity in (A) non IBC and (B) IBC tissue samples (1-9). Bottom line represents 36 bp internal controls (S-IC) and ladders represent 6 bp repeats starting with $50 \mathrm{bp}$. TSR8 quantitation control (Q) is an oligonucleotide, provided with the kit, with a sequence identical to the TS primer extended with 8 telomeric repeats AG(GGTTAG)7. This control serves as a standard for estimating the amount of TS primers with telomeric repeats extended by telomerase in a given extract.

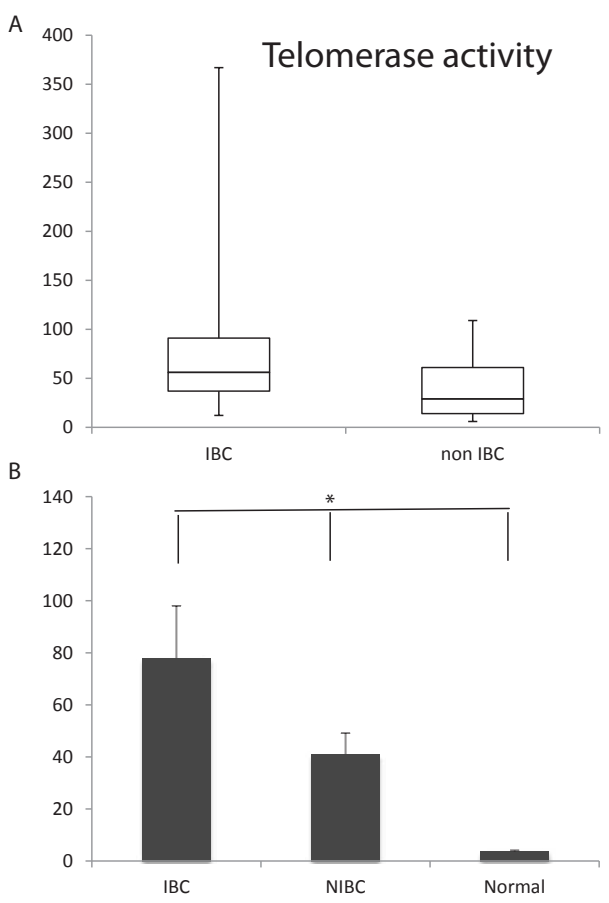

* Indicates significant $p$ value.

Figure 3: (A) Box plot of Telomerase activity values in IBC and non IBC. Minimum and maximum values of telomerase activity are depicted by upper and lower bars, the box signifies the upper and lower quartiles, and the median is represented by a short black line within the box. (B) Histogram of the mean telomerase activity in IBC, non IBC and normal tissue samples where there is a significant difference $(P<0.001)$. 
Citation: Ibrahim AM, Sabet SF, El-Shinawi M (2012) Investigation of Telomerase Activity in Inflammatory and Non Inflammatory Breast Cancer. J Cancer Sci Ther 4: 360-367. doi:10.4172/1948-5956.1000168

activity between IBC and non-IBC samples was determined to be statistically significant $(\mathrm{P}<0.05)$. The difference in telomerase activity between IBC and normal samples was determined to be statistically extremely significant $(\mathrm{P}<0.001)$. The difference in telomerase activity between non-IBC and normal samples was determined to be statistically significant $(\mathrm{P}<0.01)$.

\section{The correlation between telomerase activity and the number of positive metastatic lymph nodes in IBC and non IBC patients}

In IBC, the correlation between the telomerase activity and the lymph node metastasis was mild positive $(\mathrm{r}=0.53)$ and the $P$ value was 0.004 . In NIBC, the correlation was mild positive $(\mathrm{r}=0.54)$ and the $P$ value was 0.01 .

The correlation was made for 25 of 26 IBC and 22 of 27 patients whose clinical data was available (Table 1 and Figure 4); some patients' samples had the same telomerase activity and so they were presented with the same dot on the scatter plot.

\section{Over expression of hTERT by carcinoma cells in paraffin tissue sections of IBC versus non-IBC}

In IBC samples, hTERT expression was detected in IBC carcinoma cells and observed mainly in the nucleus and a faint signal in the cytoplasm, Also, IBC samples presented tumor emboli showed very dense nuclear and cytoplasmic staining (Figure 5) and the specimens without tumor emboli showed dense staining as well (Figure 6B). In non-IBC samples, a weaker signal than IBC samples was observed in the nucleus and also in the cytoplasm (Figure 6A). Interestingly, normal tissues didn't exhibit hTERT expression signal at all with the same antibody dilution and condition (Figure 7).

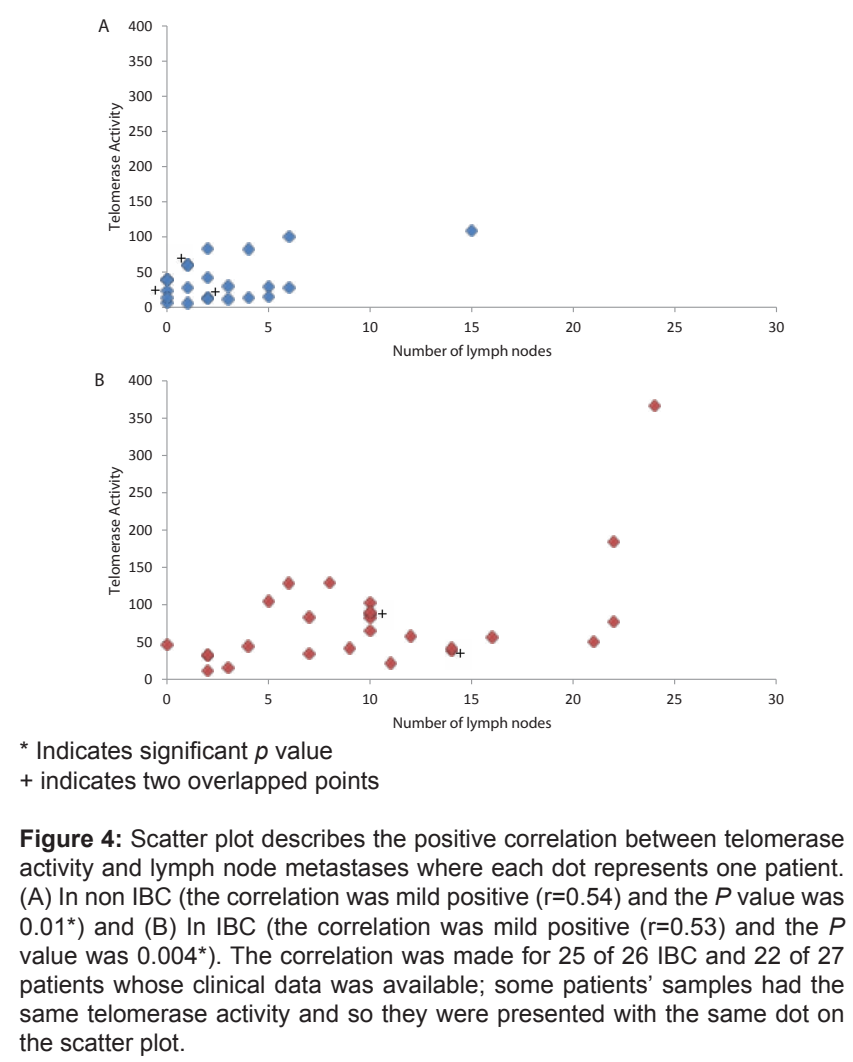

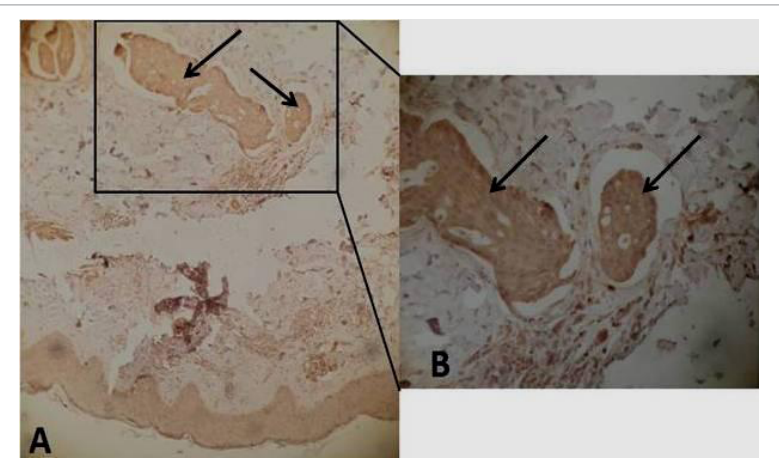

Figure 5: Immunohistochemical staining of an inflammatory breast tissue sample showing the expression of hTERT in tumor emboli. A. with original magnifications, X100 B. with original magnifications, X400.
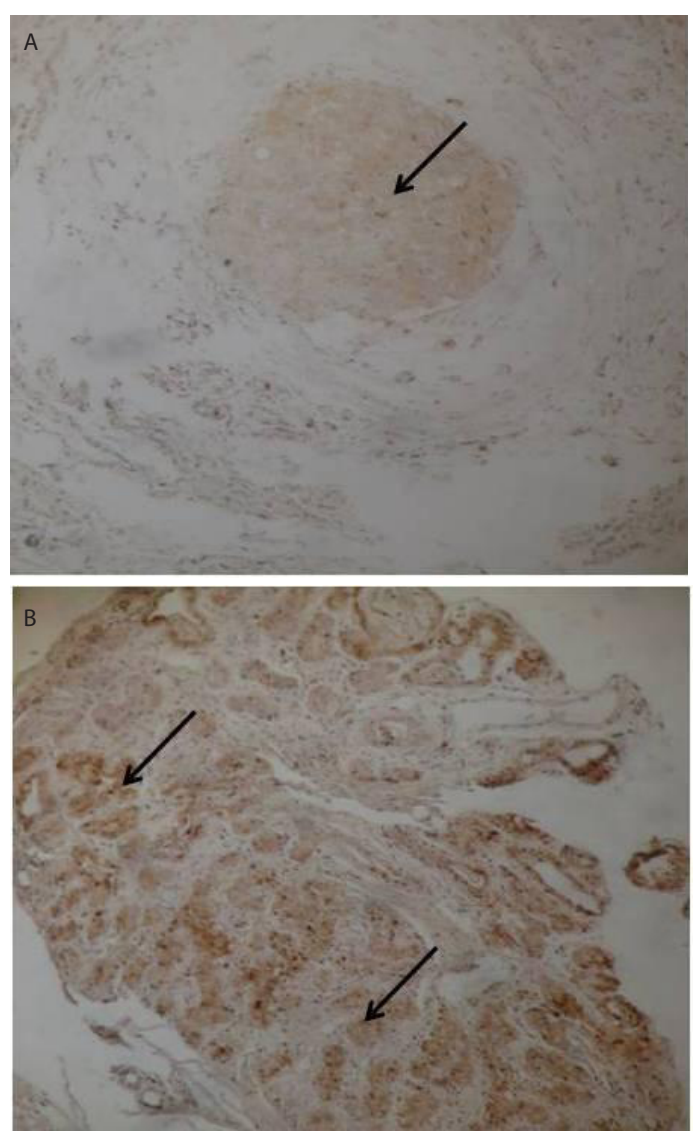

Figure 6: Immunohistochemical staining using anti-hTERT sera of a (A) non inflammatory and $(B)$ of inflammatory breast tissue sample. hTERT positive tumor cells showed brown nuclei (arrows) by 3,3'-diaminobenzidine (DAB) according to the protocol described previously Original magnifications, X100.

\section{Discussion}

In this study, we investigated telomerase activity in inflammatory and non inflammatory breast cancer tissue samples. The clinical and pathological features are very important in diagnosis of breast cancer cases and some of them are critical in the differentiation between inflammatory and non inflammatory breast cancer (Table 1) [39-41].

In our study, we found that the number of axillary lymph nodes in IBC was significantly higher than those involved in non-IBC $(\mathrm{P}<0.001)$ 


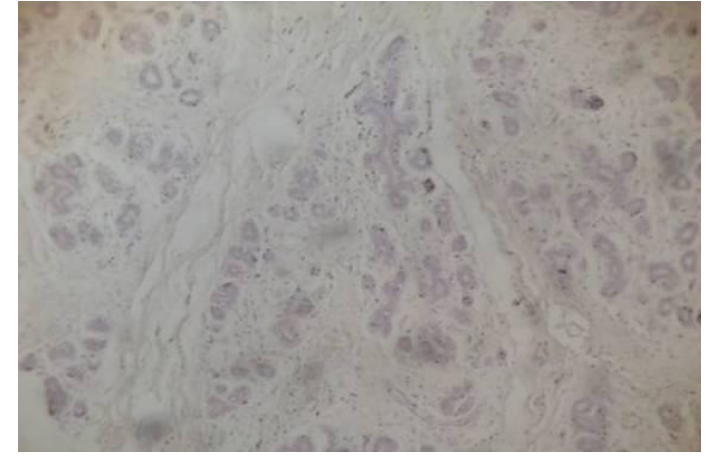

Figure 7: Immunohistochemical staining using anti-hTERT sera of a normal tissue shows negative reactivity. Original magnifications, $\mathrm{X} 100$

where $39 \%$ only of the non-IBC patients have $(\geq 4)$ metastatic lymph nodes while $76 \%$ of the IBC patients have $(\geq 4)$ metastatic lymph nodes. This finding agrees with other data that reported that the lymph node involvement is a significant prognostic factor in inflammatory breast cancer [42-44]. Moreover, other studies suggested that the increased number of positive lymph nodes was observed in IBC patients $[14,43,45]$ which thus indicates the aggressiveness of metastasis of the inflammatory breast cancer cells.

We made several attempts at quantifying telomerase activity depending on measuring the bands intensity of telomerase product for each tissue sample (telomerase ladder) in each lane using ImageJ software for this purpose and the outcome data was arbitrary and relative according to handling and equipment provided.

Due to the extremities in data within the IBC and non-IBC groups, a non parametric test was done using medians for comparison which showed an extreme significance between IBC, non-IBC and normal samples. When multiple comparisons were made between groups, there was a significant difference between each group, IBC and nonIBC $(\mathrm{P}=0.018), \mathrm{IBC}$ and normal $(\mathrm{P}=0.006)$, and non-IBC and normal $(\mathrm{P}<0.001)$. Hence, this significance shows the higher telomerase activity in IBC than non IBC and the very low or absent activity in normal. This finding supports our hypothesis that there is a difference in the level of telomerase activity between inflammatory and non-inflammatory breast cancer and according to the results it can be a promising marker for the differentiation between these subtypes taking into consideration that normal tissues showed no or very low activity of the enzyme. Moreover, the value of the telomerase activity in normal tissues can be taken as a cut off value supported by further studies and more tissue samples enrollment and with more standardization of results.

These results were confirmed by immunohistochemical analysis on tissues of representative samples for IBC, non-IBC and normal tissue samples and it showed a difference in staining intensity where IBC samples showed higher staining intensity than non-IBC samples while normal tissue gave no reaction at all and it was found that hTERT expression in breast cancer tissue samples (IBC and non-IBC) was not exclusive in nucleus as expected but also found in cytoplasm. This finding is consistent with a recent study which investigated the telomerase (hTERT) expression in different cancers like cervical, endometrial and ovarian cancers and found a cytoplasmic expression of hTERT besides the main nuclear expression [46] and this finding would open the way to discover more roles of telomerase in the cell beside its well-known role of chromosomal stability and telomere maintenance.
A previous study conducted by Hahn et al. [47] reported that tumorigenic conversion of normal human epithelial and fibroblast cells is directly related to the expression of hTERT in combination with two other oncogenes (the simian-virus-40 large-T oncoprotein and an oncogenic allele of ras). These results indicate that the level of hTERT expression is related to the level of cancer development.

Telomerase activity was observed in previous studies to be correlated to the grade and stage of breast cancer and it was shown that the activity of the enzyme is higher in metastatic stages than non metastatic ones in breast cancer [48-51] and hence IBC is a highly aggressive and metastatic disease, telomerase activity may play a considerable role in the metastasis process. Tumor emboli, which is one of the hallmarks of IBC, is found to have tumor cells with stem cell characters (cancer stem cells) [52] and being highly proliferative. Stem cells need the telomerase enzyme to survive the continual division [53,54] and to escape the mortality stages M1 and M2 [55-57].

Recently, the role of telomerase in metastasis was investigated by several studies which found a positive correlation between the Akt activation, which is a play maker in tumor progression, vascular invasion, and distant metastasis [58,59] and the level of telomerase activity [60-62]. Moreover, epidermal growth factor receptor (EGFR) and telomerase was found to be functionally interplay besides p53 activation of stromal fibroblasts induces tumor development, invasion, and differentiation [63] taking into consideration the role of EGFR in breast cancer in several processes like angiogenesis [64], cell migration and invasion [65].

No strong correlation between number of axillary lymph nodes and telomerase activity was found when we compared the telomerase activity of each patient to its metastatic lymph nodes' number and as we noticed that some patients showed a very high telomerase activity with a high number of metastatic lymph nodes while in some patients this relation was not typically observed.

In conclusion, this work is a novel attempt to compare the telomerase expression between inflammatory and non inflammatory breast cancer and it could be a new way to more research on this issue that can be used for breast cancer diagnosis and IBC in specific depending on the significant difference in expression between those subtypes.

\section{Acknowledgments}

This work was conducted at Cancer Biology Research Laboratory (CBRL) headed by Prof. Mona Mostafa, Department of Zoology, Faculty of Science, Cairo University, Egypt. We acknowledge with special gratitude the contribution of Graduate Research Challenge Fund (GRCF) program (Faculty of science, Cairo University) for funding this work.

\section{References}

1. Hernandez BY, Green MD, Cassel KD, Pobutsky AM, Vu V, et al. (2010) Preview of Hawaii Cancer Facts and Figures 2010. Hawaii Med J 69: 223-224.

2. Omar S, Khaled H, Gaafar R, Zekry AR, Eissa S, et al. (2003) Breast cancer in Egypt: a review of disease presentation and detection strategies. East Mediterr Health J 9: 448-463.

3. Nouh MA, Ismail H, El-Din NH, El-Bolkainy MN (2004) Lymph node metastasis in breast carcinoma: clinicopathological correlations in 3747 patients. J Egypt Natl Canc Inst 16: 50-56.

4. Hance KW, Anderson WF, Devesa SS, Young HA, Levine PH (2005) Trends in inflammatory breast carcinoma incidence and survival: the surveillance, epidemiology, and end results program at the National Cancer Institute. J Nat Cancer Inst 97: 966-975. 
Citation: Ibrahim AM, Sabet SF, El-Shinawi M (2012) Investigation of Telomerase Activity in Inflammatory and Non Inflammatory Breast Cancer. $J$ Cancer Sci Ther 4: 360-367. doi:10.4172/1948-5956.1000168

5. Bastawisy A, Gaafar R, Eisa S, Amira G, Helal M (2012) Inflammatory breast cancer: is it really a separate entity? Ecancermedicalscience 6: 250 .

6. Spencer B, Banerjee M, Omar S, Khaled H, Anwar N, et al. (2011) Survival of inflammatory breast cancer patients compared to non-inflammatory breast cancer patients in Egypt. Breast J 17: 545-547.

7. Anderson WF, Chu KC, Chang S (2003) Inflammatory breast carcinoma and noninflammatory locally advanced breast carcinoma: distinct clinicopathologic entities? J Clin Oncol 21: 2254-2259.

8. Dawood S, Merajver SD, Viens P, Vermeulen PB, Swain SM, et al. (2011) International expert panel on inflammatory breast cancer: consensus statement for standardized diagnosis and treatment. Ann Oncol 22: 515-523.

9. Nouh MA, Mohamed MM, El-Shinawi M, Shaalan MA, Cavallo-Medved D, et al. (2011) Cathepsin B: a potential prognostic marker for inflammatory breast cancer. J Transl Med 9: 1.

10. Kleer CG, van Golen KL, Merajver SD (2000) Molecular biology of breast cancer metastasis. Inflammatory breast cancer: clinical syndrome and molecular determinants. Breast Cancer Res 2: 423-429.

11. Soliman AS, Banerjee M, Lo AC, Ismail K, Hablas A, et al. (2009) High proportion of inflammatory breast cancer in the Population-based Cancer Registry of Gharbiah, Egypt. Breast J 15: 432-434.

12. Dirix LY, Van Dam P, Prové A, Vermeulen PB (2006) Inflammatory breast cancer: current understanding. Curr Opin Oncol 18: 563-571.

13. Vermeulen PB, van Golen KL, Dirix LY (2010)Angiogenesis, lymphangiogenesis, growth pattern, and tumor emboli in inflammatory breast cancer: a review of the current knowledge. Cancer 116: 2748-2754

14. Bonnier P, Charpin C, Lejeune C, Romain S, Tubiana N, et al. (1995) Inflammatory carcinomas of the breast: a clinical, pathological, or a clinical and pathological definition? Int J Cancer 62: 382-385.

15. Kleer CG, van Golen KL, Braun T, Merajver SD (2001) Persistent E-cadherin expression in inflammatory breast cancer. Mod Pathol 14: 458-464.

16. Tomlinson JS, Alpaugh ML, Barsky SH (2001) An intact overexpressed E-cadherin/alpha,beta-catenin axis characterizes the lymphovascular emboli of inflammatory breast carcinoma. Cancer Res 61: 5231-5241.

17. Meyerson M, Counter CM, Eaton EN, Ellisen LW, Steiner P, et al. (1997) hEST2, the putative human telomerase catalytic subunit gene, is up-regulated in tumor cells and during immortalization. Cell 90: 785-795.

18. Nakamura TM, Morin GB, Chapman KB, Weinrich SL, Andrews WH, et al. (1997) Telomerase catalytic subunit homologs from fission yeast and human. Science 277: 955-959.

19. Feng J, Funk WD, Wang SS, Weinrich SL, Avilion AA, et al. (1995) The RNA component of human telomerase. Science 269: 1236-1241.

20. Hug N, Lingner J (2006) Telomere length homeostasis. Chromosoma 115: 413425.

21. Hiyama K, Hirai Y, Kyoizumi S, Akiyama M, Hiyama E, et al. (1995) Activation of telomerase in human lymphocytes and hematopoietic progenitor cells. J Immunol 155: 3711-3715

22. Shay JW, Bacchetti S (1997) A survey of telomerase activity in human cancer. Eur J Cancer 33: 787-791.

23. Hiyama E, Hiyama K (2002) Clinical utility of telomerase in cancer. Oncogene 21: $643-649$.

24. Hiyama E, Hiyama K (2003) Telomerase as tumor marker. Cancer Lett 194: 221-233.

25. Koskimaa HM, Kurvinen K, Costa S, Syrjänen K, Syrjänen S (2010) Molecular markers implicating early malignant events in cervical carcinogenesis. Cancer Epidemiol Biomarkers Prev 19: 2003-2012.

26. Eissa S, Swellam M, Ali-Labib R, Mansour A, El-Malt O, et al. (2007) Detection of telomerase in urine by 3 methods: evaluation of diagnostic accuracy for bladder cancer. J Urol 178: 1068-1072.

27. Miyazu YM, Miyazawa T, Hiyama K, Kurimoto N, Iwamoto Y, et al. (2005)
Telomerase expression in noncancerous bronchial epithelia is a possible marker of early development of lung cancer. Cancer Res 65: 9623-9627.

28. Jeon HS, Choi JE, Jung DK, Choi YY, Kang HG, et al. (2012) Telomerase activity and the risk of lung cancer. J Korean Med Sci 27: 141-145.

29. Sanz-Casla MT, Vidaurreta M, Sanchez-Rueda D, Maestro ML, Arroyo M et al. (2005) Telomerase activity as a prognostic factor in colorectal cancer. Onkologie 28: 553-557.

30. Mokbel KM, Parris CN, Ghilchik M, Amerasinghe CN, Newbold RF (2000) Telomerase activity and lymphovascular invasion in breast cancer. Eur J Surg Oncol 26: 30-33.

31. Yashima K, Milchgrub S, Gollahon LS, Maitra A, Saboorian MH, et al. (1998) Telomerase enzyme activity and RNA expression during the multistage pathogenesis of breast carcinoma. Clin Cancer Res 4: 229-234.

32. Kalogeraki A, Kafousi M, leromonachou P, Giannikaki E, Vrekoussis T, et al (2005) Telomerase activity as a marker of invasive ductal breast carcinomas on FNABs and relationship to other prognostic variables. Anticancer Res 25 1927-1930.

33. Garcia CK, Wright WE, Shay JW (2007) Human diseases of telomerase dysfunction: insights into tissue aging. Nucleic Acids Res 35: 7406-7416.

34. Shay JW, Wright WE (2006) Telomerase therapeutics for cancer: challenges and new directions. Nat Rev Drug Discov 5: 577-584

35. Genestie C, Zafrani B, Asselain B, Fourquet A, Rozan S, et al. (1998) Comparison of the prognostic value of Scarff-Bloom-Richardson and Nottingham histological grades in a series of 825 cases of breast cancer: major importance of the mitotic count as a component of both grading systems. Anticancer Res 18: 571-576.

36. Kim NW, Piatyszek MA, Prowse KR, Harley CB, West MD, et al. (1994) Specific association of human telomerase activity with immortal cells and cancer. Science 266: 2011-2015

37. Gümüş-Akay G, Unal AE, Bayar S, Karadayi K, Elhan AH, et al. (2007) Telomerase activity could be used as a marker for neoplastic transformation in gastric adenocarcinoma: but it does not have a prognostic significance. Genet Mol Res 6: 41-49.

38. Kruskal WH, Wallis WA (1952) Use of Ranks in One-Criterion Variance Analysis. J Am Stat Assoc 47: 583-621.

39. Harada S, Mick R, Roses RE, Graves H, Niu H, et al. (2011) The significance of HER-2/neu receptor positivity and immunophenotype in ductal carcinoma in situ with early invasive disease. J Surg Oncol 104: 458-465.

40. Kim EK, Noh WC, Han W, Noh DY (2011) Prognostic significance of young age ( $<35$ years) by subtype based on ER, PR, and HER2 status in breast cancer: a nationwide registry-based study. World J Surg 35: 1244-1253.

41. Ahern V, Brennan M, Ung O, Kefford R (2005) Locally advanced and inflammatory breast cancer. Aust Fam Physician 34: 1027-1032.

42. Alberini JL, Lerebours F, Wartski M, Fourme E, Le Stanc E, et al. (2009) 1 18F-fluorodeoxyglucose positron emission tomography/computed tomography (FDG-PET/CT) imaging in the staging and prognosis of inflammatory breast cancer. Cancer 115: 5038-5047.

43. Michaelson JS, Chen LL, Silverstein MJ, Cheongsiatmoy JA, Mihm MC Jr, et al. (2009) Why cancer at the primary site and in the lymph nodes contributes to the risk of cancer death. Cancer 115: 5084-5094.

44. Van Laere SJ, Van den Eynden GG, Van der Auwera I, Vandenberghe M, van Dam P, et al. (2006) Identification of cell-of-origin breast tumor subtypes in inflammatory breast cancer by gene expression profiling. Breast Cancer Res Treat 95: 243-255.

45. Singletary SE, Cristofanilli M (2008) Defining the clinical diagnosis of inflammatory breast cancer. Semin Oncol 35: 7-10.

46. Kyo S, Masutomi K, Maida Y, Kanaya T, Yatabe N, et al. (2003) Significance of immunological detection of human telomerase reverse transcriptase: re-evaluation of expression and localization of human telomerase reverse transcriptase. Am J Pathol 163: 859-867.

47. Hahn WC, Counter CM, Lundberg AS, Beijersbergen RL, Brooks MW, et al 
Citation: Ibrahim AM, Sabet SF, El-Shinawi M (2012) Investigation of Telomerase Activity in Inflammatory and Non Inflammatory Breast Cancer. J Cancer Sci Ther 4: 360-367. doi:10.4172/1948-5956.1000168

(1999) Creation of human tumour cells with defined genetic elements. Nature 400: 464-468.

48. Porika M, Tippani R, Bollam SR, Panuganti SD, Thamidala C, et al. (2011) Serum human telomerase reverse transcriptase: a novel biomarker for breast cancer diagnosis. Int J Clin Oncol 16: 617-622.

49. He GP, Shui QL, Huang Y, Zhang SZ, Yu H (2004) Quantitative detection of telomerase activity and its association with clinicopathological characteristics in breast cancer. Ai Zheng 23:1041-1046.

50. Papanikolaou V, Iliopoulos D, Dimou I, Dubos S, Tsougos I, et al. (2009) The involvement of HER2 and p53 status in the regulation of telomerase in irradiated breast cancer cells. Int J Oncol 35: 1141-1149.

51. Ren H, Zhao T, Wang X, Gao C, Wang J, et al. (2010) Leptin upregulates telomerase activity and transcription of human telomerase reverse transcriptase in MCF-7 breast cancer cells. Biochem Biophys Res Commun 394: 59-63.

52. Xiao Y, Ye Y, Yearsley K, Jones S, Barsky SH (2008) The lymphovascular embolus of inflammatory breast cancer expresses a stem cell-like phenotype. Am J Pathol 173: 561-574.

53. Flores I, Cayuela ML, Blasco MA (2005) Effects of telomerase and telomere length on epidermal stem cell behavior. Science 309:1253-1256.

54. Hiyama E, Hiyama K (2007) Telomere and telomerase in stem cells. Br J Cancer 96: 1020-1024.

55. Harley CB (1991) Telomere loss: mitotic clock or genetic time bomb? Mutat Res 256: 271-282.

56. Wright WE, Pereira-Smith OM, Shay JW (1989) Reversible cellular senescence: implications for immortalization of normal human diploid fibroblasts. Mol Cell Biol 9: 3088-3092.

57. Ramirez RD, Herbert BS, Vaughan MB, Zou Y, Gandia K, et al. (2003) Bypass of telomere-dependent replicative senescence (M1) upon overexpression of Cdk4 in normal human epithelial cells. Oncogene 22: 433-444.
58. Saji M, Narahara K, McCarty SK, Vasko VV, La Perle KM, et al. (2011) Akt1 deficiency delays tumor progression, vascular invasion, and distant metastasis in a murine model of thyroid cancer. Oncogene 30: 4307-4315.

59. Sze KM, Wong KL, Chu GK, Lee JM, Yau TO, et al. (2011) Loss of phosphatase and tensin homolog enhances cell invasion and migration through AKT/Sp-1 transcription factor/matrix metalloproteinase 2 activation in hepatocellula carcinoma and has clinicopathologic significance. Hepatology 53: 1558-1569.

60. Kang SS, Kwon T, Kwon DY, Do SI (1999) Akt protein kinase enhances human telomerase activity through phosphorylation of telomerase reverse transcriptase subunit. J Biol Chem 274: 13085-13090.

61. Heeg S, Hirt N, Queisser A, Schmieg H, Thaler M, et al. (2011) EGFR overexpression induces activation of telomerase via PI3K/AKT-mediated phosphorylation and transcriptional regulation through Hif1-alpha in a cellular model of oral-esophageal carcinogenesis. Cancer Sci 102: 351-360.

62. Yamada O, Ozaki K, Nakatake M, Kakiuchi Y, Akiyama M, et al. (2010) Akt and $\mathrm{PKC}$ are involved not only in upregulation of telomerase activity but also in cell differentiation-related function via mTORC2 in leukemia cells. Histochem Cel Biol 134: 555-563.

63. Okawa T, Michaylira CZ, Kalabis J, Stairs DB, Nakagawa H, et al. (2007) The functional interplay between EGFR overexpression, hTERT activation, and p53 mutation in esophageal epithelial cells with activation of stromal fibroblasts induces tumor development, invasion, and differentiation. Genes Dev 21: 2788 2803.

64. De Luca A, Gallo M, Aldinucci D, Ribatti D, Lamura L, et al. (2011) Role of the EGFR ligand/receptor system in the secretion of angiogenic factors in mesenchymal stem cells. J Cell Physiol 226: 2131-2138.

65. Zuo JH, Zhu W, Li MY, Li XH, Yi H, et al. (2011) Activation of EGFR promotes squamous carcinoma SCC10A cell migration and invasion via inducing EMTlike phenotype change and MMP-9-mediated degradation of E-cadherin. J Cel Biochem 112: 2508-2517. 